\title{
Habitus Petani Sawah Berlahan di Bawah 0.5 Hektar dalam Memenuhi Nafkah Keluarga
}

\author{
Purwito Z. Rahmadi ${ }^{1}$, Bambang Santosa \\ Universitas Sebelas Maret
}

\begin{abstract}
The purpose of this research is to know the habitus of rice paddy farming under 0.5 hectares in fulfilling the family's living. This research uses qualitative methods with a case study approach. The data-sensing technique uses purposive sampling. The results of the study are known that habitus rice farmers with land ownership of less than $0.5 \mathrm{Ha}$ in Kolomayan Village in an effort to fulfill the living of their households not only rely on farming activities but by running other alternatives outside of farming activities such as debt to neighbors or close relatives. With strong social capital owned by agents easily access other capitals, such as accessing economic capital. This is expected to solve the problem of living in an effort to fulfill household living.
\end{abstract}

Keywords : Habitus, Farmers, Family

\begin{abstract}
Abstrak
Tujuan penelitian ini untuk mengetahui habitus petani sawah berlahan di bawah 0.5 hektar dalam pemenuhan nafkah keluarga. Penelitian ini menggunakan metode kualitatif dengan pendekatan studi kasus. Teknik pengampilan data menggunakan purposive sampling. Hasil penelitian diketahui bahwa habitus petani sawah dengan kepemilikan lahan kurang dari 0,5 Ha di Desa Kolomayan di dalam upaya memenuhi nafkah rumahtangganya tidak hanya mengandalkan aktifitas bertani namun dengan menjalankan alternatif lain diluar aktifitas bertani seperti berhutang kepada tetangga atau saudara dekatnya. Dengan kuatnya modal sosial yang dimiliki agen dengan mudah mengakses modal-modal lainnya, seperti mengakses modal ekonomi. Hal ini diharapkan mampu menyelesaikan masalah hidup dalam upaya pemenuhan nafkah rumah tangga.
\end{abstract}

Kata Kunci : Habitus, Petani Sawah, Keluarga

\section{Pendahuluan}

Letak Indonesia tepat dibawah garis imajiner khatulistiwa membuat Indonesia menjadi negara beriklim tropis. Kondisi iklim dan tanah yang cocok untuk melakukan usaha pertanian sehingga Indonesia disebut sebagai negara agraris, artinya pertanian memegang peranan penting dari keseluruhan perekonomian nasional. Hal ini karena banyaknya penduduk atau tenaga kerja yang

\footnotetext{
${ }^{1}$ Purwitozanuar@student.uns.ac.id
} 
hidup atau bekerja pada sektor pertanian atau dari produk nasional yang berasal dari pertanian.

Dalam sensus pertanian tahun 1983 mencatat ada sekitar $80 \%$ dari total penduduk tinggal dan berada di pedesaan dengan sumber ekonomi dari usaha tani pertanian dan memelihara ternak sebagai sampingan (Wisadirana, 2004). Menurut sensus pertanian tahun 2003, di Indonesia dari jumlah total 52.90 juta rumahtangga, atau 54.90 juta rumahtangga pada tahun 2004, atau kalau hitungan Sensus Pertanian dikoreksi maka berjumlah 62.17 juta rumahtangga, maka sejumlah 24.87 juta (40 persen) adalah rumah tangga pemilik tanah, 24.05 juta ( 49 persen) adalah rumahtangga petani penyakap (tenant, pengguna lahan), dan 13.25 juta ( 21 persen) rumahtangga petani gurem (Wahono, 2006). Menurut Sensus BPS (2013) terjadi penurunan jumlah rumah tangga petani. Rumah tangga petani pada tahun 2003 sebesar 31,23 juta, turun menjadi 26,14 juta rumah tangga petani pada tahun 2013 .

Problematika tentang kemiskinan pedesaan diketengahkan oleh Boeke yang menyatakan bahwa sistem ekonomi Indonesia bersifat dual economy, dimana petani gurem yang memiliki lahan sempit yang mengolah lahan pertanian mereka dengan cara yang sangat tradisional, yang hidup secara under subsistence, berhadap-hadapan dengan ekonomi modern yang bersentuhan dengan teknologi yang modern, perdagangan internasional, dan manajemen yang modern. Penjelasan mengenai kemiskinan juga diketengahkan oleh Geertz bahwa petani miskin dan tetap miskin karena berkaitan dengan involusi pertanian dimana pertumbuhan penduduk seberapa pun jumlahnya dapat ditampung oleh pertanian padi sawah karena dikerjakan dengan sangat intensif dan rumit. Namun demikian, menurut Geertz, petani ibaratnya berjalan di air, tidak maju tetapi sekedar mempertahankan diri agar tidak tenggelam. Pada tahun 1970'an hasil penelitian Masri Singarimbun dan DH Penny di Sriharjo Kabupaten bantul menghasilkan sebuah tesis yang menyatakan bahwa too many people but to small land (Slamet dalam Seminar Nasional Laboratorium Sosiologi, halaman 7).

Pertanian khususnya di Jawa mengalami kepadatan tenaga kerja pertanian, sementara luas lahan tetap, dan cenderung luas lahan semakin berkurang. Selain itu, permasalahan pada petani yang belum terselesaikan mulai dari biaya tanam yang 
tidak sebanding dengan harga jual yang didapat petani. Bukan hanya musim (cuaca/iklim) yang tidak menentu menjadi masalah bagi petani, tetapi permasalahan pupuk juga datang musiman. Fenomena kelangkaan pupuk setiap datangnya musim tanam, yang selalu menjadi pemberitaan media masa. Pekerjaan para petani dalam mengolah lahan pertanian yang berat. Seperti ancaman matinya tanaman sebelum petani memperoleh hasil panen (penyakit bulai pada jagung) membuat petani harus mengeluarkan biaya tambahan untuk itu, biaya yang dikeluarkan petani untuk obatobatan pertanian (fungisida, insektisida,dan pembasmi gulma). Serta ditambah lagi pupuk yang ketersediaannya saat dibutuhkan petani menjadi langka/terbatas, yang membuat petani terpaksa harus membeli pupuk dengan harga yang tinggi (membeli pupuk bukan subsidi). Banyaknya biaya untuk keperluan dalam proses produksi pertanian, belum tentu akan sebanding dengan harga jual yang diterima petani saat panen raya tiba. Harga jual yang diterima petani cenderung turun disaat panen raya, dikarenakan jumlah hasil panen yang berlimpah.

Masyarakat petani yang berada di Desa Kolomayan, sebagai bagian dari desa di Jawa mengalami permasalahan tentang permasalahan luas lahan pertanian yang semakin sempit serta harus menanggung beban kebutuhan rumah tangga petani. Kepemilikan lahan pertanian di Desa Kolomayan tidaklah sama diantara masing-masing petani (rata-rata dibawah 0,5 ha). Penduduk atau keluarga petani di Desa Kolomayan dalam pemilikan lahan pertanian didominasi petani berlahan sempit di bawah 1 Ha. Dari jumlah keluarga petani yaitu 1.016 keluarga, hanya 3 keluarga yang memiliki lahan pertanian kurang dari $10 \mathrm{Ha}$ atau di atas $1 \mathrm{Ha}$. Selebihnya didominasi oleh keluarga petani yang memiliki tanah pertanian sempit dibawah 1 Ha yaitu ada 817 Keluarga, kemudian keluarga petani yang tidak memiliki lahan sendiri ada 72 keluarga (Monografi Desa Kolomayan Tahun 2012).

Menurut Ritzer (2012) analisa teori sosial dalam mengurai berbagai masalah sosial, dapat menjawab persoalan pada masyarakat terutama terkait patologi sosial, pendidikan, politik dan juga ekonomi. Apabila salah satu kebutuhan tersebut tidak terpenuhi atau tidak tercukupi maka akan memunculkan beragam problematika sosial dalam masyarakat. Dalam kehidupan masyarakat terdapat struktur sosial yang dapat difungsikan untuk menimalisir problematika sosial. 
Dinamika keterbatasan lahan pertanian yang di garap petani di Desa Kolomayan, kondisi pada observasi penelitian ditemukan mayoritas petani yang hanya memiliki lahan garapan kurang dari 0.5 hektar. Strategi petani berlahan kurang dari 0,5 hektar dalam pemenuhan nafkah keluarga di Desa Kolomayan tersebut, menjadi dasar minat peneliti untuk melakukan kajian tentang strategi pemenuhan kebutuhan rumah tangga petani. Bagimana dinamika pertanian dengan penggaran petani yang berlahan kurang dari 0.5 hektar di desa Kolomayan. Bagaimana upaya petani untuk pemenuhan nafkah keluarga dari hasil pertaniannya. Untuk menganalisa masalah tersebut akan dianalisis ke dalam teori Pierre Bourdieu. Pierre Bourdieu salah satu tokoh sosiologi Perancis yang sangat terkenal mengemukan teori tentang Habitus sebagai bagian dasar dalam pembentukan praktik sosial.

Menurut Bourdieu, habitus adalah struktur mental atau kognitif yang diinternalisasikan (internalized) yang melaluinya individu memahami kehidupan sosial. Habitus menghasilkan dan dihasilkan dari bermasyarakat. Lapangan adalah jaringan hubungan dari berbagai posisi obyek, struktur lapangan membantu memaksa dan menghambat agen yaitu individu atau kolektif" (Ritzer dan Goodeman, 2004). Bahwa habitus diadopsi melalui pengasuhan dan pendidikan. Konsep tersebut digunakan pada tingkatan individu. Habitus merupakan hasil keterampilan yang menjadi tindakan praktis (tidak harus selalu disadari) yang kemudian diterjemahkan menjadi suatu kemampuan yang kelihatannya alamiah dan berkembang dalam lingkungan tertentu. Dalam memperoleh ketrampilan itu struktur-struktur yang dibentuk berubah menjadi struktur-struktur yang membentuk. Konsep habitus adalah kebiasaan atau tabiat yang melekat dalam diri seseorang. Habitus pada diri seseorang tidak akan permanen, habitus bukanlah sesuatu yang tetap tetapi, akan selalu bergerak mempunyai pergulatan dengan struktur dan menginternalisasi dari luar serta mengeksternalisasi dari dalam. Habitus diperoleh melalui internalisasi struktur dunia sosial kolektif tentang sejarah individual, dengan demikian ia sekaligus merupakan faktor pembeda dan penyatu, individuasi dan sosiasi. Di satu sisi lain, habitus diperoleh dari internalisasi struktur dunia sosial yang dialami secara kolektif oleh agen-agen yang hidup dalam dunia sosial yang 
sama. Kesamaan inilah yang memungkinkan keteraturan dan keserasian praktik dan representasi yang dihasilkan agen-agen dalam kelompok atau kelas yang sama.

\section{Metode Penelitian}

Metode Penelitian yang digunakan dalam penelitian ini menggunakan metode kualitatif, yang berusaha mendeskripsikan suatu gejala sosial tertentu (Slamet, 2006). Pendekatan penelitian ini menggunakan model studi kasus, menurut Yin (2000) bahwa penelitian studi kasus adalah penelitian yang dilakukan terhadap suatu obyek yang disebut sebagai kasus yang dilakukan secara seutuhnya, karena dengan studi kasus dapat dimungkinkan dialog antara peneliti dengan yang diteliti. Menurut Herdiansyah (2010), penelitian studi kasus adalah kejadian atau peristiwa, situasi, proses, program dan kegiatan. Kasus di dalam penelitian studi kasus bersifat kontemporer, masih terkait dengan masa kini, baik yang sedang terjadi, maupun telah selesai tetapi masih memiliki dampak yang masih terasa pada saat dilakukannya penelitian. Dengan demikian penelitian ini mengarah pada proses dan kegiatan yang masih terjadi mengenai habitus petani sawah berlahan kurang dari 0.5 hektar dalam pemenuhan nafkah keluarga.

Penentuan informan menggunakan teknik purposive sampling yaitu informan yang dipilih atau ditentukan secara sengaja oleh peneliti dengan menggunakan pertimbangan tertentu, disamping itu informan memiliki kesamaan dengan sifat atau karakterisitik subjek penelitian ini. Teknik purposive yaitu teknik mendapatkan sampel dengan memilih individu-individu yang dianggap mengetahui informasi dan masalahnya secara mendalam dan dapat dipercaya untuk menjadi sumber data (Goetz Le Compte dalam Sutopo, 2002).

\section{Hasil dan Pembahasan}

\section{Deskripsi Lokasi}

Desa Kolomayan memiliki luas wilayah \pm 497.035 Ha berada di ketinggian \pm 167 meter diatas permukaan air laut dengan suhu rata-rata harian 29-33 derajat celcius. Jumlah penduduk sebanyak 7.105 orang dengan rincian penduduk laki-laki 3.542 orang dan perempuan 3.563 orang. Jarak Desa Kolomayan dengan pusat 
pemerintahan kecamatan yakni Kecamatan Wonodadi adalah sekitar $\pm 5 \mathrm{~km}$. Sedangkan jarak Desa Kolomayan dengan Ibukota kabupaten yakni Kabupaten Blitar adalah $\pm 20 \mathrm{~km}$, jarak Desa Kolomayan dengan Ibukota Provinsi yakni Provinsi Jawa Timur adalah $\pm 150 \mathrm{~km}$. Secara administrasi Desa Kolomayan memiliki 3 Dusun, $7 \mathrm{Rw}, 23 \mathrm{Rt}$, dan organisasasi kemasyarakatan lainnya ada 8 kelompok tani di Desa Kolomayan. Secara geografis Desa Kolomayan terletak di antara Desa Kerjen (Kecamatan Srengat) di sebelah timur, Desa Ringinanom (Kecamatan Udanawu) di sebelah utara, Desa Kunir (Kecamatan Wonodadi) di sebelah selatan, dan Desa Pikatan (Kecamatan Wonodadi) di sebelah barat. Letak atau posisi wilayah Desa Kolomayan bisa dikatakan memiliki akses cukup baik.

Di Desa Kolomayan musim penghujan berlangsung selama lima bulan dengan suhu rata-rata harian $\pm 33^{\circ}$ Celcius. Bentang wilayah yang rendah di Desa Kolomayan ini menyebabkan udara yang relatif panas-sejuk karena terletak di ketinggian $167 \mathrm{M}$ dari permukaan air laut dan areal lahan pertanian yang masih luas. Iklim adalah rata-rata keadaan cuaca dalam waktu yang cukup lama. Iklim dipandang sebagai kebiasaan-kebiasaan alam yang berlaku dan digerakkan oleh gabuangan dari unsur-unsur iklim yaitu : radiasi matahari, temperatur, kelembaban, awan, tekanan, udara, kecepatan angin, dan curah hujan. Berdasarkan Data Monografi Desa Kolomayan tahun 2012 suhu harian rata-rata berkisar $33^{\circ} \mathrm{Celcius.}$

\section{Kondisi Kependudukan}

Penduduk di Desa Kolomayan memiliki tingkat heterogenitas yang rendah, sehingga masyarakatnya cenderung homogen dalam hal hal agama, pekerjaan, maupun komposisi yang lain. Sektor Pertanian/peternakan mendominasi mata pencaharian penduduk di Desa Kolomayan, yaitu petani/peternak dengan jumlah 741 orang dan Buruh tani/kuli dengan jumlah 868 orang. Kemudian di tempat kedua ada PNS dengan jumlah 82 orang. Kemudian tempat ketiga sektor swasta dengan jumlah 57 orang. Pedagang ada sebanyak 20 orang. Dari data monografi desa, mayoritas penduduknya memeluk agama Islam sebanyak 3563 orang. Dan tidak ditemukan warga yang memeluk agama selain Islam di Desa Kolomayan. Dalam hal kepercayaan/agama di Desa Kolomayan tingkat homogenitasnya tinggi. 


\section{Sarana Pendidikan dan Kesehatan}

Sarana pendidikan dan kesehatan yang ada di Desa Kolomayan cukup untuk memenuhi kebutuhan masyarakat Desa Kolomayan, berikut kondisi sarana pendidikan dan sarana kesejatan yang ada di Desa Kolomayan yang digunakan masyarakat. Lembaga yang ada di Desa Kolomayan ada Play Group yang berjumlah 2 unit, Taman Kanak-Kanak sebanyak 5 unit. Jumlah guru di Play Group ada 4 orang dengan siswa berjumlah 35 orang, sedangkan jumlah guru Taman KanakKanak sebanyak 15 orang dengan siswa 207 orang. Juga terdapat 1 pondok pesantren yang dimanfaatkan warga untuk memperdalam ilmu agamanya.

Jumlah dokter umum atau dokter spesialis tidak ada, Jumlah dokter prakter/mantri ada 2 oeang, Di Desa Kolomayan juga ada pelayanan kesehatan nonmedis seperti dukun desa. Pelayanan kesehatan yang disediakan pemerintah Desa Kolomayan untuk ibu posyandu tersedia dibimbing oleh 1 bidan desa, dengan bertempat di kantor desa. Pelayanan kesehatan yang disediakan di Desa Kolomayan sering dimanfaatkan untuk pemeriksaan kesehatan dasar penduduk di Desa Kolomayan. Atau, sering kali penduduk memilih pergi ke kota karena sara kesehatan yang lebih lengkap, dan akses dari desa ke kota sangat mudah dan dekat bagi penduduk Desa Kolomayan.

Desa Kolomayan memiliki 4 unit masjid dan 18 unit mushola/langgar. Dengan jumlah penduduk yang cukup besar, sarana peribadatan tersebut masih cukup untuk memenuhi kebutuhan penduduk akan sarana peribadatan. Selain untuk peribadatan, fungsi masjid dan mushola di Desa Kolomayan juga difungsikan untuk kegiatan keagamaan lainnya seperti TPA bagi anak-anak.

\section{Aktifitas Ekonomi Masyarakat}

Secara ekonomi dan mata pencaharian, maka aktivitas masyarakat Desa Kolomayan terpusat pada aktivitas yang bersifat petanian. Artinya sebagian besar masyarakat di Desa Kolomayan bekerja sebagai petani, atau pun buruh tani, masing-masing dengan jumlah petani 741 orang, dan buruh tani sebesar 868 orang. Menurut data dari Monografi Desa Kolomayan 2012, maka penduduk yang memiliki pekerjaan sebagian besar sebagai petani dan buruh tani. Adapun pekerjaan 
lain diluar pertanian adalah sebagai pegawai negeri dengan jumlah 82 orang, bekerja pada sektor swasta 57 orang, dan pedagang berjumlah 20 orang.

Banyak warga masyarakat yang bekerja di bidang pertanian, membuat sektor ini begitu penting bagi kehidupan warga masyarakat Desa Kolomayan. Pertanian di Desa Kolomayan didominasi oleh pertanian musiman, artinya jenis tanaman yang ditanam petani disesuaikan dengan musim yang berlangsung. Jenis tanaman yang ditanam pada musim penghujan didominasi oleh tanaman padi, hal ini disebabkan oleh tanah yang terlalu banyak mengandung air, saat seperti itu yang cocok ditanam adalah padi. Petani pada musim penghujan berkesempatan untuk menanam padi yang akan menghasilkan gabah, yang akan disimpan oleh petani untuk kebutuhan pangan sehari-hari sampai waktu tanam padi kembali. Karena musim tanam padi di Desa Kolomayan sebagian besar hanya dilakukan satu kali tanam/panen.

Pada musim kemarau, jenis tanaman yang ditanam petani lebih bervariatif lagi. Berbagai tanaman dihasilkan petani berupa jagung, cabai, kacang tanah, dan beberapa jenis sayur-sayuran. Selain pertanian, peternakan juga mendominasi dalam aktivitas ekonomi di Desa Kolomayan. Dimana komoditas peternakan terbanyak adalah peternakan ayam broiler/petelur, burung puyuh/petelur, sebagian kecil sapi perah.

Untuk peternakan kecil atau peliharaan rumahan, didominasi oleh ayam kampung dan sapi pedaging. Usaha ternak rumahan ini dilakukan warga masyarakat di Desa Kolomayan selain bertani di sawah.

\section{Kondisi Pertanian Di Desa Kolomayan}

Desa Kolomayan memiliki lahan pertanian seluas \pm 284.437 Ha. Kondisi tanah di Desa Kolomayan berwarna abu-abu, dengan tektur tanah pasiran. Sebagai dampak dari abu letusan Gunung Kelud yang bercampur dengan tanah, yang terjadi sejak zaman purba sampai sekarang (status Gunung Kelud yang masih aktif:tidur). Sehingga menghasilkan warna tanah keabu-abuan dan juga membuat tanah di Desa Kolomayan subur. 
Tanah sawah yang berada di Desa Kolomayan, sebagian besar luas lahan telah teraliri air dari irigasi seluas $\pm 284.275 \mathrm{Ha} / \mathrm{m}^{2}$. Dan Sisanya, seluasnya 65 $\mathrm{Ha} / \mathrm{m}^{2}$ adalah tanah sawah setengah irigasi, sementara tanah sawah seluas $97 \mathrm{Ha} / \mathrm{m}^{2}$ adalah tanah sawah tadah hujan. Tingkat kemiringan yang rendah sebesar $5^{\circ}$ derajat, membuat lahan sawah di Desa Kolomayan sangat cocok untuk bercocot tanam tanaman pangan (padi,jagung, dan sayur-sayuran). Walaupun demikian, Kebutuhan air yang dialirkan melalui irigasi tidak dapat di penuhi karena sungai utama penyupali air irigasi kering pada waktu musim kemarau, dan kembali mengalir di saat musim penghujan datang. Biasanya, petani di Desa Kolomayan pada waktu musim kemarau sering menggunakan pompa air (diesel) untuk mengairi tanaman di lahan persawahan mereka.

\section{Kebutuhan Dasar Rumah Tangga Tani}

Setiap indivdu yang hidup di dunia ini, mempunyai kebutuhan pokok yang wajib dipenuhi agar dapat bertahan hidup. Kebutuhan dasar yang wajib dipenuhi setiap orang seperti makan dan pakaian. Tetapi individu bertahan hidup bukan sekedar untuk memenuhi kebutuhan biologisnya semata. Kebutuhan-kebutuhan akan muncul sebagai akibat dari proses interaksi individu di dalam dunia sosial. Kehidupan masyarakat desa terutama desa pertanian. Warga masyarakat Desa Kolomayan, kebutuhan warga masyarakat desa terutama petani dalam mempertahankan hidupnya bukan hanya memenuhi kebutuhan dasar saja, tetapi petani harus juga menyiapkan kebutuhan tanam berikutnya.

Pekerjaan pada dasarnya adalah suatu yang saling berhubungan untuk mengubah satu wujud benda ke wujud benda lain yang memiliki nilai pakai dan nilai tukar. Pekerjaan yang dilakukan petani memiliki bagian-bagian keterkaitan erat dari mulai bagian penyiapan tanam, perawatan tanaman, sampai panen. Tahapan-tahapan pekerjaan dilakukan petani yang masih utuh inilah yang membuat petani memiliki kedekatan dengan alam. Merawat tanaman di sawah bagi petani hampir sama dengan merawat anak mereka sendiri, harus dilakukan dengan penuh ketekunan dan ketelatenan. Pekerjaan mereka yang dilakukan berulang-ulang tersebut, secara tidak langsung mempengaruhi pola pikir dan emosional mereka. Pengaruh-pengaruh kekuatan alam masih kuat dalam setiap kegiatan ekonomi 
mereka. Dimana kebergantungan petani sawah terhadap alam masih relatif kuat, hal ini berdampak pada aspek kehidupan para petani yang relatif bersahaja, arsitektur rumah yang sederhana,kedekatan dengan alam membawa petani untuk berikap pasrah (nrimo) sebagai jalan hidup yang harus dilalui. Sikap kebersahajaan atau kesederhanaan hidup ini salah satunya terlihat dalam kebutuhan konsumsi makanan pokok mereka yang sederhana. Dengan demikian, alam dalam kata lain tempat tinggal petani sawah. Mereka tidak dapat menolak keinginan alam, pengaruh tersebut yang membuat mereka bersikap rendah hati (apa anane), yang akan berdampak pada kehidupan sehari-hari mereka.

Suatu rumah tangga, bahwa pendidikan kepada anak-anak adalah suatu hal yang penting untuk diberikan sebagai bekal masa depan. Tidak terkecuali pada rumah tangga petani sawah di Desa Kolomayan. Pendidikan kepada anak-anak tidak bisa lagi sepenuhnya berasal dari pengajaran yang diberikan oleh orang tua dirumah. Menginjak usia dewasa pendidikan diserahkan kepada sekolah-sekolah formal, dan tentunya ada biaya-biaya pendidikan yang harus dikeluarkan oleh rumah tangga petani sawah di Desa Kolomayan. Biaya pendidikan yang harus dikeluarkan oleh rumah tangga petani sawah di Desa Kolomayan ada, manakala didalam rumah tangga tersebut masih terdapat anak-anak dengan usia sekolah.

Kebutuhan akan biaya-biaya pendidikan tentunya berbeda-beda setiap rumah tangga petani sawah. Tergantung dari tingkat satuan pendidikan yang sedang ditempuh anak-anak petani sawah di Desa Kolomayan. Jelas bahwa biaya pendidikan anak Sekolah Dasar berbeda dengan anak sekolah Menengah Pertama dan akan lebih tinggi lagi biaya yang akan dikeluarkan oleh petani sawah apabila bersekolah pada jenjal Sekolah Menengah Atas dan sampai melanjutkan ke Perguruan Tinggi.

Pembayaran listrik merupakan kebutuhan yang digunakan oleh petani sawah di Desa Kolomayan untuk penerangan rumah dan kegiatan-kegiatan lainnya, hampir setiap rumah tangga di Desa Kolomayan telah berlangganan listrik kepada PLN (Perusahaan Listrik Negara), dengan adanya listrik untuk penenrangan rumahrumah di Desa Kolomayan tidak lagi menggunakan lampu minyak, dan lebih terlihat terang pada gelapnya malam. Namun petani sawah harus menambah 
pengeluaran yang harus disiapkan setiap bulannya oleh petani sawah di Desa Kolomayan untuk membayar tagihan listrik.

Warga masyarakat di Desa Kolomayan masih memegang tradisi budaya yang diwariskan oleh generasi terdahulunya. Untuk selalu hidup rukun dan mengedepankan kebersamaan. Bentuk-bentuk tradisi yang masih dipegang oleh warga masyarakat di Desa Kolomayan adalah Tradisi Slametan atau Kendurenan. Tradisi ini sering dilakukan warga masyarakat Desa Kolomayan dengan mengundang tetangga sekitar rumah,saudara dan kerabat untuk melaksanakan doa bersama sesuai hajat yang diinginkan tuan rumah. Ada dua hajatan slametan yang sering dilaksanakan, yaitu slamatan syukuran, dan slamatan untuk mendoakan keluarga yang sudah meninggal dunia (berkaitan skiklus hidup). Slamatan untuk keluarga yang sudah meninggal dunia ini berlangsung secara berurutan mulai dari 1 sampai hari ketujuh setelah meninggal, 40 hari (petangpuluhan), 100 (satusan), tahun pertama (pendak pisan), tahun kedua (pendak pindo), dan 1000 hari (sewunan),

Selain itu ada tradisi-tradisi slamatan yang sering dilakukan oleh warga masyarakat Desa Kolomayan, yang berkaitan dengan hari-hari besar keagamaan (khususnya hari besar dalam agama Islam). Seperti tradisi suroan atau disini (Desa Kolomayan) lebih dikenal Baritan, slametan yang dilakukan warga masyarakat dengan berkumpul di tengah perempatan atau pertigaan, dan masing-masing membawa makanan dari rumah, yang di taruh dalam daun pisang yang disebut takir (lipatan daun pisang diberi hiasan janur/ mirip dengan pincuk, tetapi takir di kedua ujung sisinya diberi lidi sebagai pengait). Selanjutnya, ada slamatan memperingati hari-hari besar Islam, seperti maulid Nabi Muhammad SAW atau lebih dikenal dengan Muludan, slamatan "Bersih Desa". Untuk slamatan yang sifatnya umum/yang memiliki hajat adalah semua warga, pelaksanaannya berada di mushola/masjid.

Selain itu ada pula slamatan yang sering dilakukan warga masyarakat Desa Kolomayan, biasanya slamatan tersebut berkaitan dengan hal-hal penting yang menyangkut hidup seseorang, seperti kehamilan (wanita), sunat (laki-laki), pernikahan, dan perayaan slamamatan lainnya. 
Pokok bahasan kebudayaaan bukan saja pada tataran seni dan tradisi yang berlaku pada suatu masyarakat, melainkan juga hubungan sosial, seperti pada warga masyarakat Desa Kolomayan yang tercerrmin dalam interaksi individu dalam hubungan ketetangggaan. Kondisi kehidupan sosial seperti ini menimbulkan hubungan-hubungan yang akrab, serba informal, serta permisif (bebas -santai). Suasana seperti itu mampu menumbuhkan kepedulian sosial yang tinggi, saling tolong menolong satu sama lainnya.

Kebiasaan saling tolong-menolong antar warga masyarakat Desa Kolomayan ini, diwujudkan dalam bentuk tenaga maupun dalam bentuk materiil (benda/barang). Ukuran bantuan tidaklah pasti, untuk bantuan berupa barang tidak ada standarisasi jumla yang pasti, tetapi ada nilai-nilai kepantasan yang berlaku di dalam warga masyarakat desa kolomayan.

Ukuran kepantasan sebagai pertimbangan memberi sesuatu kepada tetangga, mengindikasikan bahwa petani sawah di Desa Kolomayan masih mengutamakan hubungan-hubungan sosial daripada hubungan-hubungan ekonomik. Masyarakat petani di Desa Kolomayan masih menyikapi pertanian sebagai way of life, dengan menggantungkan hidup dan hubungan sosial pada pertanian. Kondisi keluarga dan lingkungan mereka yang mendorong untuk hidup bersahaja, peduli pada tetangga dan saudara. Petani lebih masih cenderung mengutamakan rasionalitas sosial (social rationality) ketimbang rasionalitas ekonomi (economy ratinality).

\section{Habitus Petani Sawah}

Dalam menjalani hidup aktor/agen ada di dalam sebuah ranah sosial/masyarakat yang merupakan arena perjuangan yang mencoba untuk membedakan dirinya dengan yang lain, dan mendapatkan modal yang berguna di arena tersebut. Hal yang penting adalah memperoleh rejeki halal yang dapat digunakan untuk memenuhi nafkah rumah tangganya. Praktik-praktik atau tindakan yang digunakan para aktor (petani sawah) dalam berusaha untuk memenuhi kebutuhan minimum rumah tangganya ditengah masyarakat. Praktik-praktik yang dilakukan oleh setiap petani sawah memang sangat beragam. Bagi para petani sawah yang hanya memiliki sedikit ketrampilan dalam sebuah ranah perjuangan 
yang dinamis menjadi suatu titik tolak ukur untuk mereka berkembang dan mengembangkan keterampilan yang sangat minim. Setiap petani sawah memiliki habitus yang berbeda-beda dalam hal ini tidak ada petani sawah yang memiliki sejarah hidup yang sama persis. Namun habitus petani sawah juga dibentuk melalui pengalaman-pengalaman yang diperoleh dari internalisasi struktur dunia sosial yang dialami secara kolektif oleh agen-agen (petani sawah) yang hidup dalam dunia sosial yang sama. Kesamaan inilah yang memungkinkan keteraturan dan keseraian praktik dan representasi yang dihasilkan agen-agen dalam kelompok yang sama. Hal ini seperti yang diungkapkan oleh Bapak RHMdan Bapak NGL sebagai berikut:

"Mbiyen isih cilek wes biasa bantu-bantu nang sawah, golek suket kanggo pakan wedhus/ sapi... songko kui dadi belajar ngerti tani". Dulu masih kecil biasa bantu-bantu di sawah, atau cari rumput buat makanan kambing/sapi... dari situ bisa belajar mengerti tani (wawancara 22 November 2014).

"biasa nang sawah kat cilik, kat wes iso kerjo bantu-bantu nang sawah". Biasa di sawah sejak kecil, mulai bisa membatu disawah (wawancara 6 November 2014).

Dengan habitus yang telah ditanamkan dari lingkungan tempat tinggalnya, dengan begitu mereka akan menggunakan pengalaman-pengalaman mereka untuk bertindak yang dahulunya biasa dilakukan oleh orang tuanya. Tindakan-tindakan yang mereka lakukan semenjak kecil hingga menjadi petani membuat mereka lebih siap dan mandiri dalam bekerja karena sudah terbiasa dengan apa yang mereka lakukan sebelumnya. Kemandirian yang dibentuk oleh keluarga inilah yang sekarang ini ketika mereka bekerja di sawah mereka lakukan terus menerus. Apalagi bertani adalah ativitas ekonomi keluarga dimana seluruh anggota keluarga terlibat didalamnya. Hal ini seperti yang diungkapkan oleh Bapak ABD dalam wanwancara berikut ini:

"yo sudah digariskan rejekine di pertanian kok, orang tua dulu dadi petani nerusne orangtua, meneruskan pekerjaan orang tua, kalo dapat warisan sawah kalo tidak di teruskan ya eman-eman". Ya sudah digariskan cara dapat rejekinya di tani, orang tua dulu jadi petani ya sekarang melanjutkan orangtua, kalo dapat warisan sawah kalau tidak dilanjutkan ya sayang kan (wawancara 13 November 2014). 
Hal ini sama dengan pengakuan dari Bapak PN sebagai berikut:

"yo wes kadung rejekine lewat dadi petani arep piye meneh, dilakoni ae. Wes turun temurun lah mas, mbiyen wong tua tani saiki nerusne tani...". Ya terlanjur rejekinya lewat jadi petani mau gimana lagi, dijalani saja. Sudah turun temurun lah mas (wawancara 30 November 2014).

Tempat tinggal para petani sawah yang saling berdekatan, letak lahan persawahan yang saling berdekatan, dan adanya hubungan kekerabatan, membuat mereka saling berinteraksi dengan sesamanya. Dengan adanya interaksi satu sama lain akan mempengaruhi pola pikir petani satu dengan petani yang lain sehingga muncul pengalaman baru yang diperolehnya. Habitus dapat berubah dengan mengintegrasikan pengalaman barunya kedalam dirinya. Hal ini seperti yang diungkapkan Bapak RDW dan Bapak RHM sebagai berikut:

"Apa lho masalahnya, paling seng dadi masalahe petani yo mung tandurane ora urip, lek lombok kenek petek (bosok), lak enek masalah ngono kui yo biasa podo crito karo liyane, mengko enek seng wenehi solusine, enek seng ngomongi dikon tuku obat iki, gen lomboke ora bosok...”. Apa lho masalahnya, paling yang dadi masalahnya petani iya Cuma tanamannya mati, kalau tanam cabai buahnya kena petek (membusuk), kalau da masalah seperti itu biasanya saling cerita sama yang lain, nanti ada yang memberi solusi, ada yang ngasih tahu disuruh beli obat ini biar mencegah cabainya tidak busuk (wawancara 13 \&22 November 2014).

Pertanyaan tersebut senada dengan pertanyaan oleh Bapak ABD sebagai berikut:

"Tandurane mati sakdurunge panen, biasane kui nyerang nang tanduran jagung, dadi putih-putih ngono jagunge, lek ngarani wong-wong jagune kaji, Terus lek ngono kui yo isone mung dibongkar terus ditandurine, nambah ragat eneh kanggo nyulami tuku benih...". Tandurannya mati sebelum panen, biasanya itu banyak menyerang di tanaman jagung, jadi daunnya warna putih-putih. Terus kalau begitu begitu bisanya ya cuman dibongkar dan ditanami lagi, jadi tambah biaya tanam lagi buat beli benihnya (wawancara 17 November 2014).

Ketika petani mengalami kesulitan mereka melakukan kebiasaan dengan cara meminta bantuan. Kesulitan yang mereka hadapi biasanya berupa kesulitan finansial. Dengan begitu mereka melakukan tindakan sesuai dengan pengalaman yang pernah mereka lakukan yang sudah biasa dilakukan pada saat kondisi-kondisi tertentu. Hal ini seperti yang diungkapkan Bapak NGL sebagai berikut: 
"Biasane, kalo tidak punya uang pinjam tetangga, untuk beli pupuk, obat semprot. Lek ra enek lek ra minjem po meneh. Duiite entek ya pinjam. Nyaurre yo pas wes panen". Biasanya kalau tidak punya uang ya pinjam tetangga, untuk beli pupuk, beli obat semprot. Kalau tidak punya uang kalau tidak pinjam mau bagaimana lagi. Mengembalikannya kalau udah panen (wawancara 6 November 2014).

Kebiasaan meminjam ini sudah dilakukan mereka (petani sawah) sudah lama, ketika mereka bekerja dan mengalami kesulitan, mereka akan melakukan kebiasaan meminjam, biasanya mereka akan meminjam kepada tetangga atau saudara. Kebiasaan meminjam/hutang ini dilakukan mungkin dengan menirukan kebiasaan kebiasaan pendahulu mereka. Karena pinjam-meminjam adalah bagian dari tolong-menolong yang sudah mengakar kuat dalam kebiasaan mereka seharihari.

Pada umunya dalam kehidupan sosial ekonomi masyarakat sudah menjadi sebuah kebiasaan jika mengalami kesultan ekonomi adalah dengan cara meminjam pinjaman uang. Kebiasaan meminjam uang tersebut telah menjadi kesadaran dan menjadi sikap tersebut tertanam dalam dirinya pada gilirannya kebiasaan itu berfungsi sebagai kerangka untuk memahami dunia sosialnya, dan nilai-nilai dalam bertindak agen yang dipengaruhi oleh kondisi objektif kulturalnya. Karena telah ditumbuhkannya tindakan-tindakan yang berkaitan dengan meminta pinjaman uang ketika sedang mengalami masalah finansial dengan meminjam uang kepada tetangga atau saudara. Bahwa habitus petani sawah ini merupakan sepontanitas karena secara keseluruhan menyatu dengan nilai-nilai yang dianut oleh agen. Tetapi juga bukanlah gerakan mekanis yang tanpa latar belakang kebiasaan yang mereka lakukan. Seperti yang diungkapkan oleh Bapak PN berikut ini:

"Yo yen lagi ra nyekel duwet tenan ki langsung golek silian duet, jenenge kepepet, lek ora due duet nyileh kui yo wes biasa..." Ya kalau pas tidak pegang uang itu langsung cari pinjaman uang, namanya juga kepepet, kalau tidak punya uang ya pinjam, itu ya sudah biasa (wawancara 20 November 2014).

Hal ini juga senada dengan pernyataan dari Bapak NGL sebagai berikut ini:

“...Lek ra enek lek ra minjem po meneh. Duiite entek ya pinjam....” Kalau tidak ada kalau tidak pinjam mau apalgi. Uang habis ya pinjam (wawancara 6 November 2014). 
Bahwa kebiasaan petani sawah dalam menyikapi hidupnya bukanlah sekedar gerakan mekanis, melainkan sebuah kebiasaan yang mempnyai latar belakang sejarah dan latar belakang sosial. Latar belakang ini sangat jelas dari kebiasaan pinjam meminjam uang atau meminta bantuan ini yakni adanya kesengajaan dalam proses terbentuknya tindakan. Kesengajaan itu karena adanya tujuan yang lebih. Kesengajaan itulah yang membedakan dari sekedar gerakan mekanistis. Tujuan yang jelas dari kebiasaan meminjam uang atau meminta bantuan kepada orang lain adalah untuk memenuhi kebutuhan petani sawah agar dapat melangsungkan gerak putaran roda kehidupan. Dengan demikian habitus bekerja di bawah aras kesadaran, dengan menyatu dalam nilai-nilai yang dianut oleh agen.

\section{Pembahasan}

Perjalanan pembangunan pertanian Indonesia hingga saat ini masih belum dapat menunjukkan hasil yang maksimal jika dilihat dari tingkat kesejahteraan petani dan kontribusinya pada pendapatan nasional. Pembangunan pertanian di Indonesia dianggap penting dari keseluruhan pembangunan nasional. Ada beberapa hal yang mendasari mengapa pembangunan pertanian di Indonesia mempunyai peranan penting, antara lain: potensi Sumber Daya Alam yang besar dan beragam, pangsa terhadap pendapatan nasional yang cukup besar, besarnya pangsa terhadap ekspor nasional, besarnya penduduk Indonesia yang menggantungkan hidupnya pada sektor ini, perannya dalam penyediaan pangan masyarakat dan menjadi basis pertumbuhan di pedesaan. Potensi pertanian Indonesia yang besar namun pada kenyataannya sampai saat ini sebagian besar dari petani kita masih banyak yang termasuk golongan miskin. Hal ini mengindikasikan bahwa pemerintah bukan saja kurang memberdayakan petani tetapi juga terhadap sektor pertanian keseluruhan.

Bahwa sektor pertanian dari tahun ke tahun mengalami penurunan. Jumlah data rumah tangga usaha pertanian di Indonesia mengalami penurunan sebanyak 5,04 juta rumah tangga dari 31,17 juta rumah tangga pada tahun 2003 (Sensus Pertanian 2003) menjadi 26,13 juta rumah tangga pada tahun 2013, yang berarti rata-rata penurunan per tahun sebesar 1,75 persen. (BPS No. 62/09/ Th. XVI, 2 September 2013). Keadaan berkurangnya rumahtangga usaha pertanian tersebut, 
menurut Geerzt (Wisadirana, 2004) akan menyebabkan terjadinya kemiskinan yang merata atau kemiskinan bersama atau disebut share poverty, yaitu terjadinya pertambahan orang yang harus makan dari pertanian sementara produksi pertanian menjadi tetap, karena lahan pertanian yang disediakan untuk menyediakan bahan makanan juga tetap disebut bahkan menjadi semakin sempit.

Permasalahan pada petani yang belum terselesaikan mulai dari biaya tanam yang tinggi tidak sebanding dengan harga jual yang didapat petani. Bukan hanya musim (cuaca/iklim) yang tidak menentu menjadi masalah bagi petani, tetapi permasalahan pupuk juga datang musiman. Fenomena kelangkaan pupuk setiap datangnya musim tanam, yang selalu menjadi pemberitaan media masa. Pekerjaan para petani dalam mengolah lahan pertanian yang berat. Seperti ancaman matinya tanaman sebelum petani memperoleh hasil panen (penyakit bulai pada jagung) membuat petani harus mengeluarkan biaya tambahan untuk itu, biaya yang dikeluarkan petani untuk obat-obatan pertanian (fungisida, insektisida,dan pembasmi gulma). Serta ditambah lagi pupuk yang ketersediaannya saat dibutuhkan petani menjadi langka/terbatas, yang membuat petani terpaksa harus membeli pupuk dengan harga yang tinggi (membeli pupuk bukan subsidi).

Pekerjaan sebagai petani sawah dilakukan dengan memanfaatkan alam yang sudah tersedia di lingkungan sekitar mereka, Pengaruh curah hujan, kondisi tanah, kelembaban tanah, ketinggian tanah, topografi, membuat petani sawah megembangkan adaptasi terhadap alam. Di Desa Kolomayan, saat musim hujan petani beradaptasi dengan menanam padi, disamping tanaman padi tahan pada kondisi tanah yang basah dan lembab juga pada musim hujan adalah satu-satunya kesempatan petani untuk mendapatkan bahan makanan di dalam menghadapi musim kemarau yang akan datang (baca: menyimpan gabah kering). Pada musim kemarau petani lebih memilih menanam tanaman yang lebih tahan terhadap panas dan tanah yang kering akibat kurangnya kandungan air seperti, tanaman jagung, kacang tanah, dan cabai.

Pada petani sawah di Desa Kolomayan, bertani merupakan suatu usaha yang dilakukan bukan hanya dikerjakan oleh individu melainkan dari usaha bersama yang dilakukan satu keluarga, dengan memanfaatkan tenaga-tenaga semua 
anggota keluarga, sesuai kemampuan yang dimiliki masing-masing anggota dalam keluarga tersebut. Seperti mencangkul menjadi tugas laki-laki dewasa (bapak), dan memasak menjadi tugas perempuan dewasa (ibu). Sementara anak-anak memperoleh tugas membantu sesuai kemapuan mereka. Menurut Boeke dalam Rahardjo (2010), keluarga dalam ekonomi tani adalah unit swasembada, artinya membentuk suatu unit mandiri yang dapat menghidupi keluarga lewat kegiatan pertanian. Di dalam keluarga terdapat tenaga-tenaga kerja yang dapat dimanfaatkan tanpa harus diwajibkan untuk diberi upah kerja. Para petani di Desa Kolomayan menganggap keluarga juga sebagai unit ekonomi swasembada mandiri, dari keluargalah mereka mendapatkan tenaga-tenaga dalam membantu produksi pertanian mereka. Pertanian adalah usaha bersama semua anggota keluarga, dari pertanianlah mereka memenuhi kebutuhan hidupnya. Sementara tenaga yang didatangkan dari luar merupakan usaha bagi petani sawah untuk menutupi kekurangan tenaga yang ada pada keluarganya, dengan memberikan imbalan upah kepada orang lain diluar anggota keluarganya. Bila tenaga dari anggota keluarga tidak mampu membantu dalam mengerjakan lahan sawah, maka dicarikan tenaga dari luar keluarga dengan imbalan upah, yang disesuaikan dengan luas lahan yang dikerjakannya, upah diberikan bervariasi antara Rp 45.000- Rp50.000.

Di dalam pengelolaan lahan pertanian, bagi petani di Desa Kolomayan yang memiliki lahan yang sempit atau terbatas lebih memilih mengerjakan lahan mereka sendiri. Sementara bagi petani yang memiliki lahan relatif luas dan pertimbangan jumlah anggota keluarga yang tidak mampu mengerjakan semua lahan pertanian, lebih memilih menyerahkan kepada orang lain untuk mengerjakan sebagaian lahan pertaniannya dengan cara sistem bagi hasil atau dengan menyewa. Bagi pertanian di Jawa hal ini adalah wajar sebagaimana yang dijelaskan oleh Gertz (Rahardjo, 2010) disebut sebagai “berbagi kemiskinan’ (shared Poverty) adalah mekanisme warga desa untuk saling tolong menolong dengan sesamanya. Mereka yang memiliki tanah lebih luas merasa wajib untuk berbagai dengan yang lain. Hal ini menandakan juga bahwa luas lahan pertanian yang tetap, harus dikerjakan oleh jumlah rumahtangga tani yang lebih banyak dan terus bertambah. 
Masuknya sistem ekonomi uang kedalam ekonomi petani sawah di Desa Kolomayan, berdampak pada ketergantungan petani terhadap kondisi pasar yang ada diluar. Petani sawah dalam penentuan harga selalu dalam pihak yang lemah, dimana kekuatan didominasi ekonomi pasar yang diwakili oleh pedagang atau pengepul yang membeli hasil panen dari petani sawah. Hal ini membuat pendapatan yang diterima petani sawah tidak tetap, tergantung dengan pedagang yang membeli hasil panenannya. Ketidakpastian harga harus dihadapi petani sawah disetiap musim panen tiba.

Segala ketidakpastian yang harus diterima petani, membuat petani harus menjalankan beberapa strategi alternatif, agar petani sawah dapat mampu memenuhi kebutuhan minimum rumah tangganya. Dimana strategi tersebut menjaga petani sawah dari ancaman gagal panen dan rendahnya harga panen yang didapatkan petani. Menurut Redclift (1986) orang-orang dalam posisi yang termarginalkan seperti petani, kelompok usaha kecil, dan keluarga petani dikatakan memiliki strategi di dalam bertahan hidup yang sering disebut sebagai "strategi survival" atau strategi coping". Secara umum, strategi bertahan hidup (survival strategi) didefinisikan sebagai tindakan ekonomi yang disengaja oleh rumah-tangga dengan motivasi yang tinggi untuk memuaskan sebagian besar kebutuhan dasar manusia, paling tidak pada level minimum, sesuai dengan norma sosial dan budaya masyarakat (Widiyanto, 2010). Praktik sosial dari Pierre Bourdieu diuraikan melalui konsep Habitus, Modal, dan Arena. Dengan rumus $($ Habitus $\times$ Modal $)+$ Arena $=$ Praktik. Praktik disini adalah strategi dari petani sawah dalam upaya pemenuhan nafkah rumah tangga tani. Dalam kasus penelitian ini strategi petani sawah dalam upaya pemenuhan nafkah rumahtangganya, memiliki kebiasaan yang mereka lakukan di ranah/arena yang mereka tempati. Ranah/arena adalah lingkungan tempat tinggal petani sawah, dan tempat mereka bekerja. Di dalam ranah terdapat habitus dan modal yang dipertaruhkan untuk menjalankan praktik petani sawah dalam upaya memenuhi nafkah rumah tangganya.

Habitus mengarah pada pemahaman orang akan dunia sosial. Memahani, mengapresiasikan dan mengevaluasi dunia sosial. Habitus adalah sikap dari agen, yang secara dialektif, habitus adalah produk dari internalisasi struktur dunia sosial 
(Ritzer dan Goodman, 2010). Di dalam habitus semua tindakan agen tidak lepas dari pengalaman-pengalaman yang sudah melekat di dalam dirinya. Berkaitan dengan habitus, strategi petani sawah di Desa Kolomayan, di dalam upaya memenuhi nafkah rumahtangganya habitus petani sawah untuk memenuhi nafkah rumahtangga sering berhutang kepada tetangga atau saudara dekatnya, Habitus ini sering kali diulang-ulang apabila keuangan rumahtangganya sedang kekurangan, juga digunakan untuk modal tanam (pembelian pupuk,dan bibit).

Habitus-habitus tersebut diperoleh sebagai akibat dari lamanya posisi dalam kehidupan sosial yang di duduki. Sehingga Habitus akan berbeda-beda, Habitus adalah rentang sejarah individu, habitus diperoleh dari internalisasi struktur dunia sosial yang dialami secara kolektif, tergantung dimana dan bagaimana posisi agen tersebut dalam kehidupan sosial. Sehingga agen yang menduduki posisi yang sama dalam dunia sosial, cenderung akan memiliki kebiasaan yang sama. Dalam pengertian ini habitus dapat pula menjadi fenomena kolektif.

Di dalam praktik upaya strategi nafkah rumah tangga tani, agen juga memiliki modal yang mendukung praktik tersebut yakni, modal ekonomi, modal sosial, modal budaya, dan modal simbolik. Dengan modal tersebut para agen dapat menentukan posisinya di dalam setiap arena. Dari sekian modal yang dimiliki agen, bahwa modal sosial adalah modal yang paling dominan dan penting bagi strategi nafkah rumahtangga tani. Dengan kuatnya modal sosial yang dimiliki agen dengan mudah mengakses modal-modal lainnya, seperti mengakses modal ekonomi. Selain itu hubungan yang baik antara agen satu dengan yang lainnya, menumbuhkan rasa solidaritas yang tinggi sehingga menunjang strategi petani sawah dalam pemenuhan nafkah rumah tangga taninya.

\section{Kesimpulan}

Hasil penelitian yang dilakukan dapat diketahui bahwa habitus petani sawah dengan kepemilikan lahan kurang dari $0,5 \mathrm{Ha}$ di Desa Kolomayan dalam upaya pemenuhan nafkah rumah tangga, tidak hanya mengandalkan aktifitas bertani namun juga dengan menjalankan alternatif lain diluar aktifitas bertani yang 
diharapkan mampu menyelesaikan masalah hidup dalam upaya pemenuhan nafkah rumah tangga.

\section{Daftar Pustaka}

Badan Pusat Statistik Tahun 2013

Herdiansyah, Haris. 2010. Metodologi Penelitian Kualitatif. Jakarta: Penerbit Salemba Humanika.

Mutahir, Arizal. 2011. Intelektual Kolektif Pierre Bourdieu Sebuah Gerakan untuk Melawan Dominasi. Bantul: Kreasi Wacana.

Rahardjo. 2010. Pengantar Sosiologi Pedesaan dan Pertanian. Yogyakarta: UGM Press

Ritzer, George dan Goodman, Douglas J. 2004. Teori Sosiologi (Terj.) Dari Teori Sosiologi Klasik Sampai Perkembangan Mutakhir Teori Sosiologi Postmodern. Yogyakarta: Kreasi Wacana.

Ritzer, George. 2012. Teori Sosiologi: Dari Sosiologi Klasik Sampai Perkembangan Terakhir Postmodern. Yogyakarta: Pustaka Pelajar.

Ritzer, George. Goodman, Douglas J. 2010. Teori Sosiologi (Terj.) Dari Teori Sosiologi Klasik Sampai Perkembangan Mutakhir Teori Sosiologi Postmodern. Yogyakarta: Kreasi Wacana.

Slamet, Y. 2006. Metode Penelitian Sosial. Surakarta: UNS Press.

Slamet, Y. Seminar Nasional Laboratorium Sosiologi halaman 7.

Sutopo, HB. 2002. Metodologi Penelitian Kualitatif : Dasar, Teori, dan Terapannya dalam Penelitian. Surakarta: UNS Press.

Tim Penyusun. 2012. Monografi Desa Kolomayan.

Wahono, Francis. 2006. Ekososiologi Deideologi Teori Restrukturisasi Aksi. Yogyakarta: Cindelaras Pustaka rakyat Cerdas.

Widiyanto. 2010. Sistem Penghidupan dan Nafkah Pedesaan. Surakarta: UNS Press.

Wisadirana, Darsono. 2004. Sosiologi Pedesaan. Malang: UMM Press.

Yin, Robert K. 2000. Studi Kasus. Jakarta: PT Raja Grafindo Persada 